Emanuela Barasch-Rubinstein

Mephisto in the Third Reich 



\section{Emanuela Barasch-Rubinstein}

Mephisto in the Third Reich

Literary Representations of Evil in Nazi Germany

\section{DE GRUYTER}

OLDENBOURG MAGNES 
Co-published by

The Hebrew University Magnes Press (Jerusalem)

and De Gruyter (Berlin/Boston)

for the Vidal Sassoon International Center for the Study of Antisemitism

ISBN 978-3-11-037938-9

e-ISBN (PDF) 978-3-11-037943-3

e-ISBN (EPUB) 978-3-11-039578-5

Library of Congress Cataloging-in-Publication Data

A CIP catalog record for this book has been applied for at the Library of Congress.

\section{Bibliografische Information der Deutschen Nationalbibliothek}

The Deutsche Nationalbibliothek lists this publication in the Deutsche Nationalbibliographie; detailed bibliographic data are available in the Internet at http://dnb.dnb.de.

(C) 2015 Walter de Gruyter GmbH, Berlin/München/Boston

\& the Vidal Sassoon International Center for the Study of Antisemitism,

The Hebrew University Magnes Press, Jerusalem

Cover Image: kwasny221/iStock/Thinkstock

Typesetting: Dr. Rainer Ostermann, München

Printing: CPI books $\mathrm{GmbH}$, Leck

(2) Printed on acid free paper

Printed in Germany

www.degruyter.com

www.magnespress.co.il 
In memory of my father, a true Renaissance Man

Moshe Barasch 
